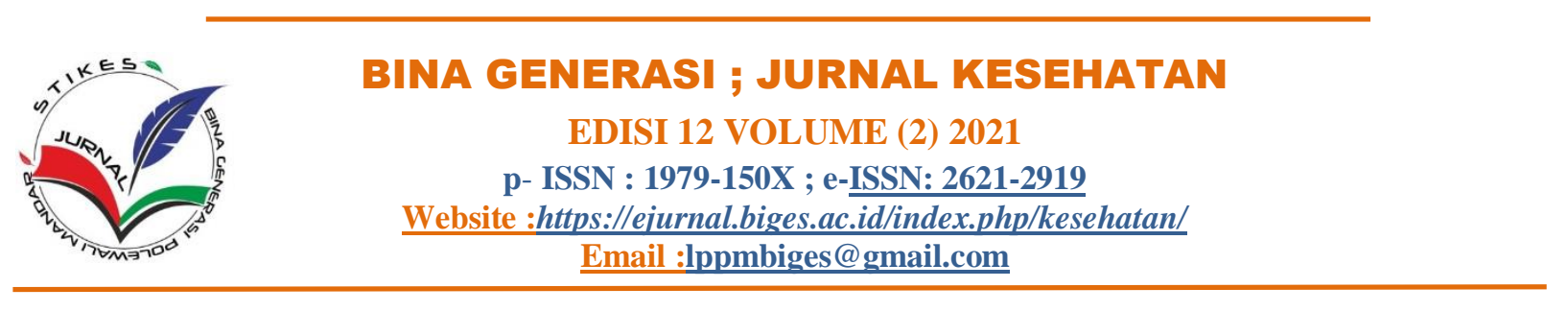

\title{
PENGARUH LATIHAN FLEKSI WILLIAM (STRETCHING) TERHADAP TINGKAT NYERI PUNGGUNG BAWAH PADA LANSIA
}

\author{
Masyitah Wahab ${ }^{1}$, Wahyuni ${ }^{2}$ \\ ${ }^{1,2}$ STIKES Bina Generasi Polewali Mandar \\ Masyitahwahab08@gmail.com \\ Wahyunizumar@gmail.com
}

Keywords:

william flexion

(stretching), low

back pain

\begin{abstract}
Health problems experienced vary in each elderly person. Some elderly people are not able to carry out activities or activities are limited due to physical problems. One of the daily physical problems often found in the elderly is lower back pain. Low back pain can be caused by degenerative conditions such as arthritis, osteoporosis or other bone diseases.The purpose of this study was to analyze the effect of william's flexion exercise (stretching) on the level of lower back pain in elderly.The research method used is the pre-experiment method using the design of one group pre testpost test. This study used 20 samples based on inclusion criteria, where the sampling technique was purposive sampling technique, where the researcher collecterd samples with certain considerartion, where the measuring instrument used was the Numeric Rating Scale (NRS) observsion sheet. The results of the statistical test study found that the intervention group ( $P$ $=0,000$ ) had the influence of william's flexion exercise (stretching) on the level of low back pain in the elderly.Based on the results of the study showed that william's flexion exercise (stretching) will affect the decrease in the level of low back pain in the elderly.
\end{abstract}

\section{PENDAHULUAN}

Nyeri punggung bawah termasuk salah satu gangguan muskuloskletal yang sering terjadi(Sari,2015). Nyeri punggung bawah dapat didefinisikan sebagai rasa nyeri dan ketidaknyamanan di area punggung bawah atau bawah tulang rusuk dan di atas lipatan gluteal. Nyeri punggung bawah dapat disebabkan oleh kondisi degeneratif misalnya penyakit arthritis, osteoporosis atau penyakit tulang lainnya seperti infeksi virus, iriasi pada sendi dan discuss dan kelainan bawaan tulang belakang (Nurzannah dan Sinaga, Salmah 2015).

Nyeri punggung bawah (NPB) merupakan keluhan yang sering dijumpai dan umum dalam masyarakat hampir setiap orang pernah merasakn nyeri punggung bawah dalam hidupnya. 
Organisasi Kesehatan Dunia(WHO), melaporkan bahwa sekitar $80 \%$ orang yang menderita NPB. NyeriPunggungbawah menjadi perhatian dan dianggap sebagai salah satu masalah yangcukup besar karena mempengaruhi sektor industri sehinggaberpengaruh besar pada pertumbuhan ekonomi negara terutama dinegara barat (Dagenais, 2008). Kasus NPB pada usia 18-56 tahunterdapat lebih dari 500.000 di Amerika, persentase NPB mengalamikenaikan sebanyak 59\% dalam kurun waktu 5 tahun. Sekitar 80\%-90\% kasus NPB dapat sembuh dengan spontan dalam waktu sekitar 2 minggu (Wheeler, 2013).

Prevalensi nyeri punggung bawah banyak terjadi di wilayah Asia Timur dan Asia Tenggara. Nyeri punggung bawah berdasarkan hasil studi sebesar $62 \%$ terjadi pada pria, dan mayoritas dialami usia 35-55 tahun. Peningkatan kasus nyeri punngung bawah karena pekerjaan antara 1990 dan 2010 sebesar 22\%. Hasil studi menyimpulkan bahwa nyeri punggung bawah muncul akibat paparan ergonomi di tempat kerja adalah penyebab utama dari kecacatan sehingga perlu peningkatan pemberian informasi tentang distribusi paparan dan risikonya terutama di negara berkembang (Driscoll et al., 2014).

Di Indonesia nyeri punggung bawah merupakan masalah kesehatan yang nyata. Data untuk jumlah penderita nyeri punggung bawah di Indonesia belum diketahui secara pasti, namun diperkirakan penderita nyeri di Indonesia bervariasi antara 7,6\% sampai $37 \%$ dari jumlah penduduk yang ada di Indonesia. Kira-kira $80 \%$ penduduk seumur hidup pernah sekali merasakan NPB. Pada setiap saat, lebih dari $10 \%$ penduduk menderita NPB. Insidensi NPB di beberapa negara berkembang lebih kurang $15-20 \%$ dari total populasi, yang sebagian besar merupakan nyeri punggung akut maupun kronik. Dan berdasarkan diagnosis yang telah dilakukan oleh tenaga kesehatan, prevalensi penyakit muskuloskeletal di Indonesia sebesar 7,3\% dan prevalensi penyakit muskuloskeletal di Sulawesi Barat mencapai 3,2\% (Riskesdas, 2018).

William Flexion Exercise diperkenalkan oleh Dr. Paul Williams.Program latihan ini banyak ditujukan pada pasien-pasien kronik nyeri punggung bawah (NPB) dengan kondisi degenerasi corpus vertebra sampai pada degenerasi diskus. Program latihan ini telah berkembang dan banyak ditujukan pada laki-laki dibawah usia 50 tahun dan wanita dibawah usia 40 tahun yang mengalami lordosis lumbal yang berlebihan, penurunan space diskus antara segmen lumbal dan gejala-gejala kronik nyeri punggung bawah (NPB).

Adapun tujuan dari William Flexion Exerciseadalah untuk mengurangi nyeri, memberikan stabilitas lower trunk melalui perkembangan secara aktif pada otot abdominal, gluteus maksimus, dan hamstring, untuk meningkatkan fleksibilitas/ elastisitas pada group otot fleksor hip dan lower back (sacrospinalis),serta untuk mengembalikan/menyempurnakan

keseimbangan kerja antara group otot postural fleksor \& ekstensor.

Hasil penelitian Hangga Kusuma dan Anies Setiowati pada tahun 2015 yang berjudul "Pengaruh William Flexion Exercise terhadap Peningkatan Lingkup Gerak Sendi Penderita NyeriPunggungBawah di Rs. Mardirahayu Kudus", pemberian latihan dilaksanakan selama 5 minggu dengan 3 kali pertemuan setiap minggu dan dengan waktu satu kali latihan 20 menit. Hasil penelitian menunjukkan William Flexion Exercise dapat meningkatkan lingkup gerak sendi dengan nilai rata-rata pada gerak fleksi $15,1^{\circ}$ dengan nilai (pvalue $=0,000$ ), ekstensi $13,5^{\circ}$, $(\mathrm{p}$ value $=0,000)$, abduksi 10,3 $(\mathrm{p}$ value $=0,000)$, adduksi $11,8^{\circ}(\mathrm{p}$ value $=$ 0,000). Kesimpulan dalam penelitian ini adalah William Flexion Exercise berpengaruh terhadap peningkatanlingkup gerak sendi penderitanyeripunggungbawah.(Kusuma \& Setiowati, 2015). 
Berdasarkan data yang diperoleh peneliti dari Puskesmas Mapilli bahwa terdapat 12 posyandu lansia yang berada dibawah binaan Puskesmas Mapilli dan Posyandu Lansia Desa Bonra kecamatan Mapilli merupakan salah satu posyandu lansia dengan penderita nyeri punggung bawah terbanyak. Dimana angka penderita nyeri punggung bawah pada tahun 2017 sebanyak 20 lansia yang berkunjung keposyandu dengan keluhan nyeri punggung bawah sedangkan pada tahun 2018 meningkat dengan jumlah 30 lansia.

Berdasarkan uraian diatas, peneliti melakukan penelitian tentang pengaruh latihan fleksi william (stretching) terhadap tingkat nyeri punggung bawah pada lansia di PosyanduLansiaDesaBonraKecamatanMapilli.

\section{METODE PENELITIAN}

Desain penelitian yang digunakan dalam penelitian ini adalah pra Eksperimen dengan pendekatan One Group Pre test- Post test.Penelitian ini bertujuan untuk menegetahui pengaruh pemberian latihan fleksi William terhadap penurunan tingkat nyeri punggung bawah. Penelitian ini dilaksanakan di wilayah kerja puskesmas mapilli pada waktu bulan MeiAgustus2020.

Tabel 3.1 Desain Penelitian

\begin{tabular}{|c|c|c|c|}
\hline Subyek & Pretest & Perlakuan & Postest \\
\hline KA & 0 & $\mathrm{X}$ & 01 \\
\hline
\end{tabular}

Keterangan :

KA : Kelompok eksperimen

$\mathrm{O}$ : Observasi tingkat nyeri punggung bawah sebelum dilakukan

Latihan fleksi William (stretching)

$\mathrm{X}$ : Intervensi latihan fleksi William (stretching)

01 : Observasi tingkat nyeri punggung bawah setelah dilakukan

latihan fleksi William (stretching)

\section{HASIL PENELITIAN DAN PEMBAHASAN}

\section{Karakteristik Demografi Responden}

\section{Umur}

Umur adalah usia responden pada lansia yaitu lanjut usia dini dan lanjut usia tua. Distribusi ini berdasarkan tingkat usia dapat dilihat pada tabel di bawah ini :

Tabel 1.Gambaran Distribusi RespondenBerdasarkan umur

\begin{tabular}{cccc}
\hline No. & Umur & F & \% \\
\hline $\mathbf{1}$ & 45-59 tahun & 2 & 10 \\
\hline $\mathbf{2}$ & 60-74 tahun & 14 & 70 \\
\hline $\mathbf{3}$ & 75-90 tahun & 4 & 20 \\
\hline & Jumlah & $\mathbf{2 0}$ & $\mathbf{1 0 0}$ \\
\hline
\end{tabular}

Dari Tabel 4.1 diatas dapat diketahui bahwa umur 60-74 tahun menempati urutan tertinggi yaitu sebanyak 14(70\%)responden, dan usia 45-59 sebanyak 4 (20\%) responden serta usia 75-90 tahun sebanyak $2(10 \%)$ responden. 


\section{Jenis Kelamin}

Jenis kelamin adalah berbedaan yang mendasar pada manusia yaitu laki-laki dan Jenis kelamin dapat dilihat pada tabeldi bawah perempuan. Distribusi responden berdasarkan ini:

Tabel 2.Gambaran Distribusi RespondenBerdasarkan Jenis Kelamin

\begin{tabular}{cccc}
\hline No. & JenisKelamin & F & \% \\
\hline $\mathbf{1}$ & Laki-laki & 3 & 15 \\
\hline $\mathbf{2}$ & Perempuan & 17 & 85 \\
\hline & Jumlah & $\mathbf{2 0}$ & $\mathbf{1 0 0}$ \\
\hline
\end{tabular}

Dari Tabel 2 diatas dapat diketahui bahwa jenis kelamin laki-laki sebanyak 3(15\%)

\section{Pendidikan}

Pendidikan berhubungan dengan kemampuan dalam menyerap informasi.Semakin tinggi tingkat pendidikan seseorang maka responden, dan perempuan sebanyak $17(85 \%)$ responden.

Tabel 3.Gambaran DistribusiRespondenBerdasarkanTingkatPendidikan

\begin{tabular}{cccc}
\hline No. & Pendidikan & F & \% \\
\hline $\mathbf{1}$ & SD & 20 & 100 \\
\hline & Jumlah & $\mathbf{2 0}$ & $\mathbf{1 0 0}$ \\
\hline
\end{tabular}

Sumber Data Primer Tahun 2020

semakin luas wawasan dan pengetahuannya. Distribusi responden berdasarkan tingkat pendidikan ibu dapat dilihat pada tabeldi bawah ini:

Dari Tabel 3 diatas dapat diketahui

berapa pada tingkat pendidikan SDsebanyak 20 bahwa Tingkat Pendidikan semua responden $(100 \%)$ responden.

\section{Anialisis Univariat}

\section{Tingkat Nyeri Punggung Bawah sebelum Intervensi}

Tingkat Nyeri Punggung Bawah sebelum di berikan latihan fleksi william (stretching)dapat di lihat pada tabel 4 di bawah ini :

Tabel 4.Deskripsi Tingkat Nyeri Punggung Bawah sebelumdi berikan latihan fleksi william(stretching)

\begin{tabular}{ccccc}
\hline Pre Test & Mean & SD & Minimum & Maksimum \\
\hline Tingkat Nyeri & 4.35 & 0.813 & 2 & 5 \\
\hline
\end{tabular}

Sumber Data Primer Tahun 2020

Tabel 4 diperoleh nilai rata-rata tingkat nyeri pre test sebesar 4.35 tergolong tingkat nyeri sedang, nilai standar deviasi sebesar 0.813 dengan tingakt nyeri terendah sebelum diberikan latihan fleksi william (stretching) sebesar 2 dan tingkat nyeritertinggi sebesar 5 . 


\section{Tingkat Nyeri Punggung Bawah setelah intervensi}

Tingkat NyeriPunggung Bawah setelah di berikan latihan fleksi william (stretching)dapat di lihat pada tabel 5 di bawah ini :

Tabel 4.5.Deskripsi Tingkat Nyeri Punggung Bawah setelahdi berikan latihan fleksi william(stretching)

\begin{tabular}{rccll}
\hline Post Test & Mean & SD & Minimum & Maksimum \\
\hline Tingkat Nyeri & 2.50 & 1.100 & 1 & 5 \\
\hline
\end{tabular}

Sumber Data Primer Tahun 2020

Tabel 5 diperoleh nilai rata-rata tingkat nyeripos test sebesar 2.50 tergolong tingkat nyeri ringan, nilai standar deviasi sebesar 1.100 dengan tingkat nyeri terendah setelah diberikan latihan fleksi william (stretching) sebesar 1 dan tingkat nyeri tertinggi sebesar 5 .

\section{Analisis Bivariat}

\section{Analisis Pengaruh Latihan Fleksi William (Stretching) Terhadap Tingkat Nyeri Punggung Bawah} Pada Lansia

Hasil analisis pengaruhlatihan fleksi william(stretching)terhadap tingkat nyeri pada Lansia di Posyandu Lansia desa Bonra Kecamatan Mapilli Kabupaten Polewali Mandar, dapat di lihat dalam tabel 6.berikut ini :

Tabel 6 PengaruhLatihan Fleksi William (Stretching) Terhadap

Tingkat Nyeri Punggung Bawah Pada Lansia Di Posyandu Lansia

Desa Bonra Kecamatan Mapilli

\begin{tabular}{|c|c|c|c|c|}
\hline Tingkat Nyeri & $\begin{array}{l}\text { Rerata } \\
\text { (s.b) }\end{array}$ & $\begin{array}{l}\text { Selisih } \\
\text { (s.b) }\end{array}$ & IK95\% & $\begin{array}{l}\text { P- } \\
\text { Value }\end{array}$ \\
\hline SebelumIntervensi & $4.35(0.81)$ & \multirow{2}{*}{$\begin{array}{c}1.85 \\
(1.14)\end{array}$} & \multirow[b]{2}{*}{$1.32-2.38$} & \multirow[b]{2}{*}{0.000} \\
\hline SetelahIntervensi & $2.50(1.10)$ & & & \\
\hline
\end{tabular}

Sumber Data Primer Tahun 2020

Tabel 6 diperoleh hasil bahwa perbedaan tingkat nyeri sebelum intervensi memiliki rerata 4,35dengan standar deviasi 0,81 dan terjadi penurunan setelah intervensi menjadi 2,50 dengan standar deviasi1,10. Penelitian ini dapat di percaya karena nilai mean 1,85 berada pada rentang nilai KI 95\% 1.32-2.38. dapat di simpulkan terjadi penurunan rata rata tingkat nyeri setelah pemberian latihan fleksi wiliam (stretching), walaupun terdapat 2 responden yang tingkatnyerinya tetap sama.
Hasil analisis Uji $t$ Berpasanganmengenai pengaruh latihan fleksi wiliam (stretching) terhadap tingkat nyeri punggung bawah pada Lansia dengan nilai $p$ value $=0,000<0,05$, hal ini menunjukkan Ho ditolak, sehingga disimpulkan ada terdapat pengaruh latihan fleksi wiliam (stretching) terhadap tingkat nyeri punggung bawah pada Lansiadi Posyandu Lansia Desa Bonra Kecamatan Mapilli 


\section{PEMBAHASAN}

\section{Tingkat nyeri punggung bawah pada lansia sebelum latihan fleksi William (Stretching)}

Berdasarkan Tabel 4 diperoleh nilai rata-rata tingkat nyeri pre test sebesar 4.35 tergolong tingkat nyeri sedang, nilai standar deviasi sebesar 0.813 dengan tingakt nyeri terendah sebelum diberikan latihan fleksi william (stretching) sebesar 2 dan tingkat nyeri tertinggi sebesar 5. Dapat di simpulkan bahwa seluruh responden memiliki tingkat nyeri ringan sampai sedang, dari hasil tabbulasi data dari 20 responden terdapat 2 responden yang meiliki tingkat nyeri ringan dan selebihnya tingkatnyerinya sedang.

Setelah dilakukan penelitian dari 20 responden pada tabel 1 diketahui bahwa sebagian besar responden berusia di atas 60 tahun dan hanya 2 responden usia 45-59 tahun.Menurut peneliti usia berkaitan dengan degenerasi pada tulang, kepadatan tulang semakin menurun, sehingga mudah mengalami keluhan musculoskeletal, hingga menimbulkan nyeri. Pada usia 30 tahun, degenerasi terjadi pada kerusakan jaringan, penggantian jaringan menjadi jaringan akut, serta pengurangan cairan, sehingga stabilitas pada tulang dan otot menjadi berkurang hingga mengalami penurunan elastisitas pada tulang yang menyebabkan terjadinya NPB. Tingkat nyeri punggung bawah pada responden bervariasi antara responden satu dengan responden lainnya sehingga efek yang dirasakan dari responden berbeda-beda,hal ini terlihat dari hasi lpengukuran tingkat nyeri yang telah dilakukan berbeda-beda.

Selain usia,jenis kelamin menjadi factor yang dapat menjadi factor resiko timbulnya nyeri punggung bawah pada lansia. Berdasarkan tabel 2 diketahui bahwa hamper seluruh responden adalah perempuan sebanyak 17 responden dari 20 responden $(85 \%)$.Prevalensi terjadinya NPB lebih banyak pada wanita daripada laki-laki.Secara fisiologis, kemampuan otot wanita lebih rendah daripada pria. Selain itu, wanita dengan usia kisaran 41-50 yang mulai memasuki masa menopause terjadi penurunan hormon estrogen yang mengakibatkan kepadatan tulang berkurang sehingga beresiko terjadinya nyeri punggung bawah. Menurut peneliti responden dalam penelitian ini mengalami nyeri punggung bawah walaupun hampir seluruh responden adalah perempuan, namun responden perempuan dalam penelitian ini sudah memasuki masa menopause, sehingga beresiko sama dengan lakilaki. Nyeri punggung bawah dapat dikarenakan jenis kelamin, jenis kelamin memiliki peranan penting dalam terjadinya nyeri punggung bawah.

Perempuan akan mengalami nyeri punggung bawah pada masa menopause dikarenakan masa menopause terjadi penurunan hormon estrogen yang mengakibatkan kepadatan tulang berkurang sehingga beresiko terjadinya nyeri punggung bawah.

Dari pembahasan diatas, berdasarkan usia, jenis kelamin, sangat berpengaruh dalam prevalensi nyeri punggung bawah.Diposyandu lansia responden yang mengalami nyeri punggung bawah diberikan obat-obatan untuk mengatasi radang atau rasa sakit yaitu analgesik dari golongan AINS (Anti Inflamasi Non Steroid) atau NSAID (Non Steroidal Anti Inflamatory Drugs) unruk mengurangi nyeri tulang. Namun penggunaan obat-obatan dalam jangka panjang akan menimbulkan efek yang merugikan, oleh karena itu diperlukan pengobatan nonfarmakologi sebagai alternatif intervensi dari asuhan keperawatan nyeri punggung bawah pada lansia. 
Tingkat nyeri punggung bawah pada lansia setelah latihan fleksi William (stretching)

Tabel 4.5 diperoleh nilai rata-rata tingkat nyeripos test sebesar 2.50 tergolong tingkat nyeri ringan, nilai standar deviasi sebesar 1.100 dengan tingkat nyeri terendah setelah diberikan latihan fleksi william (stretching) sebesar 1 dan tingkat nyeri tertinggi sebesar 5 .

Hasil pengukuran tingkat nyeri yang didapatkan sesudah pemberian latihan fleksi william (stretching)2 kali seminggu selama1 bulanrata rata mengalami penurunan, hanya 3 responden dari 20 responden yang tidak mengalami penurunan, hal ini dibuktikan dengan hampir seluruh responden sesudah pemberian latihan fleksi william (stretching) mengalami penurunan tingkat nyeri. Menurut peneliti penurunan tingkat nyeri yang terjadi diakibatkan oleh Latihan William's flexion exerciseini juga dapat meningkatkan stabilitas lumbal karena secara aktif melatih otot-otot abdominal, gluteus maksimusdan hamstring. Disamping itu William's flexion exercise dapat meningkatkan

\section{Pengaruh latihan fleksi William (stretching)terhadap tingkat nyeri punggung bawah pada lansia}

Tabel 4.7 diperoleh hasil bahwa perbedaan tingkat nyeri sebelum intervensi memiliki rerata 4,35 dengan standar deviasi 0,81 dan terjadi penurunan setelah intervensi menjadi 2,50 dengan standar deviasi1,10. Penelitian ini dapat di percaya karena nilai mean 1,85 berada pada rentang nilai KI 95\% 1.32-2.38. dapat di simpulkan terjadi penurunan rata rata tingkat nyeri setelah pemberian latihan fleksi wiliam (stretching), walaupun terdapat 2 responden yang tingkatnyerinya tetap sama.

Hasil analisis Uji $t$ Berpasanganmengenai pengaruh latihan fleksi wiliam (stretching) terhadap tingkat nyeri punggung bawah pada Lansia dengan nilai $p$-value $=0,000<0,05$, hal ini menunjukkan Ho ditolak, sehingga tekanan intra abdominal yang mendorong kolumna vertebralis ke arah belakang, dengan demikian akan membantu mengurangi hiperlordosis lumbal dan mengurangi tekanan pada diskus intervertebralis yang dapat mengurangi nyeri pada daerah perut dan punggung.

Pada tabel 4.5 menunjukan bahwa sesudah pemberian latihan fleksi William (stretching), diketahui bahwa terjadi penurunan rata-rata tingkat nyeri mengarah pada tingkat nyeri ringan yaitu 2.5.Tingkat nyeripada responden tidak seluruhnya mengalami penurunan sesudah pemberian latihan fleksi william(stretching). Menurut peneliti hal ini disebabkan karena faktor-faktor yang meliputi kepatuhan latihan yang di berikan, diet lansia dan tingginya kadar asam urat.Selain itu kepatuhan dalam latihan juga mempengaruhi tingkat nyeri hal ini dapat dilihat dari lansia yang tidak patuh dalam latihan, hanya beberapa gerakan responden sudah tidak mau melakukan.

disimpulkan ada terdapat pengaruh latihan fleksi wiliam (stretching) terhadap tingkat nyeri punggung bawah pada Lansia di Posyandu Lansia Desa Bonra Kecamatan Mapilli

Menurunnya tingkat nyeri pada lansia dengan nyeri punggung bawah dengan tingkat nyeri sedangkan nyeri ringan dikarenakan Latihan William's flexion exercise ini juga dapat meningkatkan stabilitas lumbal karena secara aktif melatih otot-otot abdominal, gluteus maksimusdan hamstring. Disamping itu William's flexion exercise dapat meningkatkan tekanan intra abdominal yang mendorong kolumna vertebralis ke arah belakang, dengan demikian akan membantu mengurangi hiperlordosis lumbal dan mengurangi tekanan pada diskus intervertebralis yang dapat mengurangi nyeri pada daerah perut dan punggung.Berdasarkan penelitian yang telah dilakukan terdapat pengaruh yang signifikan 
antara pemberian latihan fleksi wiliam (stretching) dengan penurunan tingkat nyeri pada lansia dengan nyeri punggung bawah.Hal ini dapat digunakan sebagai salah satu terapi non-farmakologi yang dapat dilakukan untuk menurunkan tingkat nyeri punggung bawah.

Faktor resiko yang dapat mempengaruhi nyeri punggung bawah seseorang meliputi usia, jenis kelamin, indeks massa tubuh (IMT), kebiasaan merokok, aktifitas fisik/olahraga, posisi tubuh saat bekerja serta beban kerja. Usia dan jenis kelamin akan meningkatkan kadar tingkat nyeri diakibatkan semakin menua usia fungsi sisstem muskuloskletas semakin menurun dan berakibat pada timbulnya nyeri pada persendian khususnya tulang belakang proses penuaan lansia dengan riwayat osteoporosis akan mengalami kekambuhan nyeri apabila beraktivitas berlebihan. Namun dalam penelitian ada 3 responden yang tingkat nyerinya tetap sebelum dan setelah intervensi, hal ini dikarenakan faktor ketidak aktifan mengikuti latihan fleksi wiliam (stretching)dan masih terkadang responden lupa gerakannya saat latihan serta responden mudah lelah sehingga prosedur latihan tidak dilaksanakan sepenuhnya. Berdasarkan analisa penelitian yang telah dilakukan oleh peneliti selama 1 bulan didapatkan adanya pengaruh yang signifikan terhadap tingkat nyeri punggung bawah pada lansia, dari hasil penelitian pada tabel 4.5 menunjukan terjadi penurunan rata rata tingkat nyeri sebelum dan sesudah intervensi, walaupun beberapa lansia tingkat nyerinya tidak berubah setelah intervensi. Sehingga latihan fleksi wiliam (stretching) sangat bermanfaat dalam pengobatan nonfarmakologis pada pasien dengan keluhan nyeri punggung bawah.

\section{KESIMPULAN DAN SARAN}

Penelitian ini menunjukkan

bahwaadanya Pengaruh latihan fleksi William (stretching) terhadap tingkat nyeri punggung bawah pada Lansia di Posyandu Lansia Desa
Bonra Kecamatan Mapilli dengan tingkat signifikan $p=0,000$.

\section{DAFTAR PUSTAKA}

Nurzannah. Hubungan faktor resiko dengan terjadinya nyeri punggung bawah (low back pain) pada tenaga kerja bongkar muat (Tkbm) Di Pelabuhan Belawan Medan. J Lingkung dan Keselam kerja.

Wheeler. Low back Pain. Europe: Priority Medicines for Europe and The World; 2013. 671 p.

Lionel. Risk factors for chronic low back pain. Jounal community Med Heal Educ. 2014;1-4.

Riskesdas. Laporan Hasil Riset Kesehatan Dasar (Riskesdas) Indonesia Tahun 2018. Badan Penelit dan Pengemb Kesehat Kemenkes RI. 2018;

Nurarif AH, Kusuma H. Aplikasi Asuhan Keperawatan Berdasarkan Diagnosa Medis \& Nanda Nic-Noc Edisi Jilid 1. Jogjakarta: mediaction; 2015. 170$176 \mathrm{p}$.

Notoatmodjo PDS. Metodologi penelitian Kesehatan. Jakarta: Rineka Cipta; 2010.

Sari. Hubungan Lama Duduk dengan Kejadian Low Back Pain pada Operator Komputer Perusahaan Travel di Manado. Fak Kedokt Univ Sam Ratulangi. 2015;

Sari FP. Latihan Peregangan Pada Penderita Nyeri Punggung Bawah. J Media Kesehat. 2018;11(1):046-52.

Marelly AFV. Keefektifan William Flexion Exercise Untuk Pt Argo Manunggal Triasta Kota Salatiga. 2017;

Youdas JW, Krause DA, Hollman JH, Harmsen WS, Laskowski E. The influence of gender and age on hamstring muscle length in healthy adults. J Orthop Sports Phys Ther. 2015;35(4):246-52. 
Kusumawati YR, Wahyono Y. Latihan Core Stability dan William's Flexion Dalam Menurunkan Nyeri, Peningkatan Keseimbangan, Dan Kemampuan Fungsional. J Terpadu Ilmu Kesehat. 2015;4(1):15-8.

Gerak L, Penderita S, Back LOW. Pengaruh

William Flexion Exercise Terhadap Peningkatan Lingkup Gerak Sendi Penderita Low Back Pain. JSSF (Journal Sport Sci Fitness). 2015;4(3):16-21.

Di DM, Kerja W, Kokap P, Progo IK. Pengaruh konseling keluarga terhadap perbaikan peran keluarga dalam pengelolaan anggota keluarga dengan DM di wilayah kerja puskesmas kokap i kulon progo. J keperawatan komunitas. 2010;1-18.

Ni Luh Made Dwi Padma Sari at al. Pengaruh Latihan Fleksi William Terhadap Skala Nyeri Punggung
Bawah Pada Pengrajin Ukiran. 2019;7:67-74.

Sa'adah HD. Pengaruh Latihan Fleksi William (Stretching) terhadap Tingkat Nyeri Punggung Bawah pada Lansia di Posyandu Lansia RW 2 Desa Kedungkandang Malang. J Sains Medicat. 2013;5(2):56-61.

Lestari NZ. Pengaruh fleksi william terhadap tingkat nyeri punggung bawah pada perawat pelaksana di Medan. 2020;3(1):37-42.

Pratrisna RHAN. Pengaruh Hydrotherapy Exercise dan William's Flexion Exercise Terhadap Nyeri Punggung Bawah. Prgram Stud S1 Fisioter. 2013;

WHO, W. H. (2013). Low Back Pain. Priority Medicines for Europe and The World. 81: 671-6 